\title{
ARTICLE \\ The political importance of labelling: terrorism and Turkey's discourse on the PKK
}

\author{
André Barrinha* \\ International Relations, University of Coimbra, Coimbra, Portugal
}

(Received 8 July 2010; final version received 6 December 2010)

\begin{abstract}
Labelling the 'other' is one of the most relevant aspects in an armed conflict context. Summarising what the opponent is in one single expression is a strong rhetorical tool in any belligerent discourse. The use of the 'terrorist' label assumes a particularly powerful role in such a construction. Employing Ole Wæver's layered discursive structure, this article aims to study the discursive practices and political consequences associated with the use of such labels. The political implications of using the 'terrorist' label in regards to the Kurdistan Workers' Party (PKK) in Turkish politics will be analysed as an illustrative case study. The period under analysis extends from April 2007 to January 2008, corresponding to the escalation of a security discourse that led to the (brief) Turkish military incursion in northern Iraq in the winter of 2007-2008. The political exposure and intense usage of the 'terrorist' label in this period makes it particularly ripe for understanding the political discursive context that shapes Turkey's policies towards this protracted conflict. The focus on this period also sheds light on the political reasons underlying the intractability of this conflict.
\end{abstract}

Keywords: terrorism; discourse; Turkey; PKK

\section{Introduction}

In an armed conflict ${ }^{1}$ context, discourse is often seen as part of each party's strategy - it is used to gather support, legitimacy or simply to increase the combatants' morale. In the context of this article, though, discourse is more than that. It is a constitutive element of the conflict, in the sense that the latter only has meaning through the former as 'an amalgam of material practices and forms of language and knowledge where each reinforces the other in a continuous cycle' (Jackson 2005, p. 19). This implies an understanding of language as more than a mere description of reality, an understanding in which language describes our world embedded in other discourses and is dependent on an ever, if slowly, changing context (Diez 1999, p. 610). In this sense, discourses are systems where statements are both formed and limited, as discourses set the rules and boundaries of those statements (Wæver 2002, pp. 29-30). Within those, particular words or expressions acquire a structural meaning for the way in which they reduce a particular subject or entity to a single idea, to a single label. ${ }^{2}$ As argued by Richard Jackson, 'the act of naming [or labelling] is always a highly charged process that can have serious political and social consequences' (2005, p. 23).

\footnotetext{
*Email: abarrinha@fe.uc.pt
} 
By focusing on the 'terrorist' label, it is the goal of this article to highlight the importance of discourse as both a reflection of a specific political structure and as a defining factor in the unfolding of a conflict. These labelling processes, it will be argued, are associated with a potentially long-term disruption of normal political life, ${ }^{3}$ in which counterterrorism emergency measures become routinised in the daily life of states, communities and groups.

This conceptual and theoretical study will be complemented by an analysis of how the 'terrorist' label has been included in Turkey's discourse regarding the potential invasion of northern Iraq in order to curb the Kurdistan Workers' Party (PKK) activities in that region between April 2007 and January 2008. This was a period of great political tension in Turkey, in which clashes between Turkey's armed and security forces and the PKK were becoming increasingly visible, and involved an increasingly higher number of casualties. ${ }^{4}$

The 'terrorism' discourse has been predominant in Turkish politics since the late 1980s when the conflict between the Turkish state and the PKK evolved into a fully fledged civil war (UCDP 2010). Even though the terms of the discourse remained in place, after Abdullah Öcalan's arrest in 1999, terrorism (temporarily) became a secondary issue in Turkish politics (see Bilgin 2007). In 2004, the PKK resumed its attacks and the terrorism discourse returned to the top of the political agenda. In that sense, the 2007-2008 period should be understood in the context of this discursive continuum derived from the $1980 \mathrm{~s}$, rather than as something new.

The political tension associated with this period, combined with the need to come up with a solution to resurgent high levels of violence, makes this an appropriate period of time to understand both how the political discourse framed the conflict, and defined the policies to potentially solve it. By focusing on the 2007-2008 period, this article attempts to provide some insights into the reasons why, despite the enormous social, political and economic consequences for Turkey (Jacoby 2010, pp. 99-100), Ankara's political leadership has been incapable of impeding the recurrent peaks of violence that characterise this protracted conflict. This case was chosen as an example of how a functioning state develops a circular discourse that influences the adoption of repeatedly unsuccessful policies, thus leading to the protraction of the conflict.

The article will be divided into three parts. The first part will introduce Ole Wæver's layered discursive structure and articulate it with the concept of labelling. The second part will highlight the particular ways in which the usage of the 'terrorist' label dictates the limits of a conflict, from the actors to the strategies that can be used. ${ }^{5}$ The third part will analyse the political debate in Turkey between April 2007 and January 2008 in order to understand both the relation between the structure of Turkey's political discourse and the policies adopted regarding the PKK, and how the use of a specific label to frame the debate on this issue - the terrorist label - helped in the constitution of practices of normalisation of the exceptional.

For the analysis of the case study, more than 100 news articles and official documents were selected. Particular attention was given to the views expressed by political and military leaders, as well as to the opinions of leading journalists and former politicians and diplomats, which were seen as having a direct contribution to the Turkish political debate. ${ }^{6}$ In all cases, the main goal was to: (a) identify the constellation of terms associated with PKK 'terrorism' or 'terror'; and (b) analyse how it links with the options regarding the 'threat' reproduced in the political discourse.

Due to language restraints, the vast majority of texts under analysis were published in English. In Turkey, there were until January 2008 three newspapers in English, each one representing a distinct political view (Today's Zaman with a more conservative 
view, Turkish Daily News linked to the Kemalist/secularist view and The New Anatolian sympathetic to the Justice and Development Party (AKP) government, but defined as independent). Also, there were two other newspapers, Sabah and Hürriyet, which only had Turkish print editions, but that translated the most relevant news into English. Finally, there were some services that regularly translated the main news from the other main Turkish newspapers, such as the one provided by the Turkish Ministry of Foreign Affairs. These will be the predominant sources for this article, but other international sources, such as the $B B C$ News website and International Herald Tribune, will also be taken into consideration. Even though this could be understood as a potential limitation to the analysis, as the focus was on the public speeches of the political actors and on opinion articles of influential Turkish columnists which were also published in Turkish, these English sources were seen as translators of the Turkish reality and not as creators of a particular narrative focusing on an international audience. ${ }^{7}$

\section{Labelling and the political discursive context}

The labels used in a conflict discourse set the basis of the conflict. Defining the other as an 'enemy' or as a 'terrorist' leads to different policies and practices associated with the conflict. In that sense, labelling is a central element in the construction of a belligerent discourse. As Bhatia (2005, p. 8) asserts:

Once assigned, the power of a name is such that the process by which the name was selected generally disappears and a series of normative associations, motives and characteristics are attached to the named subject. By naming, the subject becomes known in a manner which may permit certain forms of inquiry and engagement, while forbidding or excluding others.

Following a critical constructivist ontology (see Risse 2004, Fierke 2007), this article argues that there is no a priori deterministic reality. Hence, the construction of an enemy and the choice of how to face it are eminently political, an exclusionary political choice (Mouffe 1993, p. 141).

Labelling (or naming), that is 'to identify an object, remove it from the unknown, and then assign to it a set of characteristics, motives, values and behaviours' (Bhatia 2005, p. 9), is not something that occurs in an empty discursive context: it is inserted into a discursive structure that incorporates and limits its reach and meaning. Ole Wæver (2002, p. 29) defends the existence of different layers of discursive structures, each one of them incorporating a set of key concepts derived from the previous layer. Under this perspective, any political rhetoric on any given issue is dependent on a basic conceptual logic (with its codes and narratives) which that political rhetoric will reproduce and possibly modify, but that at the end of the day will set the boundaries of the political struggle (Wæver 2002, p. 31).

Even though Ole Wæver's model was defined in order to explain how states discursively define their foreign policies, it could also be used to understand how polities (usually states) define their 'conflict policies', articulating a conflict within the broader political framework under which it takes place. This methodological tool introduces two essential epistemological clarifications that are often missing in the study of conflicts, and that are, this article would argue, crucial for their understanding. First, it clearly places armed conflicts as phenomena inherently derived from political decisions, thus making it clear that armed conflict dynamics need to be apprehended by studying politics (Jabri 2006b). This means that politicians and other political actors are directly responsible for the triggering and unfolding of a conflict, which in turn, recovers conflict analysis from 
the de-politicised toolbox that is so often applied in academia (Jabri 2006b). Second, it establishes a direct link between conflicts and discourse analysis, highlighting the essential role that communication plays in the constitution and unfolding of conflicts.

This linkage has at its core a set of labels that help to frame the conflict and thus constitute it in a specific way. The central role of this labelling process therefore needs to be acknowledged in Ole Wæver's model if it is to be applied to conflict contexts. This article would argue that such acknowledgement takes place in the middle layer, in which particular issues are defined according to the constellation of key concepts that structure the political system in which decisions are taken. Hence, a revised version of Ole Wæver's model would be defined according to the following discursive layers: first, the political discursive structure layer, followed by the labelling layer and finally the policy layer.

The political discursive structure is a constellation of hegemonic concepts that defines the political and social systems within a polity and paves the way for the definition of narrower political issues. The frequent use of expressions such as 'great nation', 'free country' and 'national unity' reifies a certain discourse that becomes dominant, and that is difficult to change in the short term. Political actors work on the basis of shared basic codes, even if they completely disagree on policy contents (Wæver 2002, p. 31). This political discursive structure also sets the words that can and cannot be used, making some appear logical whereas others seem absurd; it makes some political options viable and others nonsensical (Jackson 2005, p. 22).

The second tier would be defined by the characterisation of a given situation or issue, according to the possibilities provided by the constellation of key concepts. The naming of the 'other' is conditioned by this structure, as it must use that discursive constellation in a way that makes 'logical' the choice of the label. For instance, in a political context characterised by the aggressive content of political arguments, the 'other' will most likely be defined in a way in which the political actors that promote such labelling are not seen as weak or incapable of dealing with the threat. The label must make sense within the broader political discourse.

Finally, policies correspond to the set of specific measures undertaken in order to approach a given issue or group. These measures reflect both the labels used to characterise that issue/group and the broader political discourse in which those labels have been defined. This process is further reinforced by what linguists call the binary structure of concepts, in which any concept contains its significance as well as its opposite (Jackson 2005 , p. 21). For example, discourses on terrorism are inextricably linked to the appearance and deployment of a counterterrorism discourse, which in turn leads to a whole set of practices associated with 'counterterrorism'.

Thus defined, one could be led to think this layered structure leads to an a priori deterministic process of labelling and policy-making, which is not the case. If it were so, that would mean that political leaders were not responsible for their decisions, as the structure would inevitably lead them in a certain direction. As mentioned, this is precisely what this model wants to contradict. The layered structure is composed by 'sedimented' concepts which are not easily changeable in the short term, but that are nonetheless open to re-interpretation and change: 'the deeper structures are more solidly sedimented and more difficult to politicise and change, but change is always in principle possible since all these structures are socially constituted' (Wæver 2002, p. 32).

Moreover, in the same way structures are changeable and not necessarily unidirectional, labels and policies can also lead to changes in the broader political culture, as Nadarajah and Sriskandarajah (2005, p. 98) demonstrate regarding the usage of the 'terrorism' label in the Sri Lankan conflict: 
The deliberate conflation of 'terrorism' with the Tamil political project by successive Sri Lankan governments has produced a political culture in which the main (Sinhala) parties routinely vie to adopt more hard-line positions on the 'ethnic question' - a practice which began as long ago as 1956 .

This example shows that the middle layer can affect both the policies that are adopted, and the broader political culture in which it is inserted. It also highlights the particular discursive power associated with the terrorist label, as will now be analysed.

\section{The terrorist label}

The usage of the terrorist label could be defined as a powerful contextualised political choice. Powerful, as it has attached the 'metaphysical punch' and 'disciplinary power' (Der Derian 1995, pp. 24-25) that anything related to security has, but also because any 'deployment of language by politicians is an exercise of power' (Jackson 2005, p. 3). Contextualised, as the terrorist discourse must be framed by a broader discourse that contains the constellation of key concepts (national security, identity, etc.) that define what can and cannot be politically articulated. Political choice, because terrorism is defined as a phenomenon linked to the practice of violence in order to obtain political goals, hence, defined within the boundaries of politics. The choice of the terrorist wording is, in that sense, an acceptance of its political character, and as such, a political utterance.

In analysing the terrorist label in particular contexts, it is essential to understand what is inside of it; that is to understand who are the actors, institutions and countries that are being brought together under the same words. This delimitation step is of fundamental importance, not only for the audience to understand the boundaries and content of the label, but for the conflict analyst to be able to better understand the limits of the conflict (who, according to the belligerent actors, is or is not part of the conflict). In a conflict where formally the state fights against a non-governmental entity, a first distinction that state authorities must make is between the 'internal' and the 'external'. The discourse must be constructed either in a way that considers the rebel movement mainly as a proxy of an external actor, or in a way that acknowledges it mainly as an internal issue.

In the first case, the rhetoric will be directed towards the country or countries in support of the rebels. In this case, the conflict might easily evolve into a regional confrontation. In the second case, the discourse construction can broadly assume three different levels. The first level is the one in which the rebel movement is treated in an isolated way: belligerents are not given identity labels or even political ones. They are taken as a movement looking to destabilise the country or to create some kind of conflict dynamics that benefits them. They are usually defined as 'terrorists', a label that carries 'a connotation of absolutely illegitimate violence' (Guelke 2006, p. 182), and the impossibility of negotiations (Guelke 2006, p. 211). In the Sri Lankan case, as Nadarajah and Sriskandarajah reveal, state authorities established a clear boundary between the Liberation Tigers of Tamil Eelam (LTTE) and the Tamil people, "insisting its military campaign was intended to "liberate the Tamils from the LTTE" ' (2005, p. 93). There was, in this case, a clear distinction between a group and the citizens - the latter under the state umbrella, the former, enemies that should be destroyed.

The second level goes into the political arena, absorbing the 'collaborators', usually legal political parties. In that context, there is already a broader network in place, in which the rebel movement tries to combine the illegal means (the use of violence against the 
state) with legal political participation, such as the Irish Republican Army (IRA)/Sinn Fein in Ireland (see Bew et al. 2009). These are usually leitmotivs for closing down political parties, as has frequently happened in Turkey (Koğacioloğlu 2004).

Finally, the third level goes all the way to the community. It is more than a rebel movement, more than a political party: it is an ethnic group, a minority, a whole community challenging the state. The 'other' must, in this case, be defined as inferior, and as damaging to the stability of the state (see de Swaan 1997). It is broadly the same kind of discourse employed by the Nazis during the Jewish genocide and that has been reproduced in several different conflicts around the world, from Rwanda to Darfur. It is a type of discourse that tries to create insurmountable barriers between communities or groups within the same state. There is an attempt for general popular mobilisation, which, as a consequence, may lead to communal violence or even genocide (see Shaw 2007). Following a Schmittian approach, it could be argued that, as a political tool, genocide falls beyond the limits of politics itself, as the enemy is to be destroyed and not defined. It is the passage from the real enemy to that of the absolute enemy: '[i]t is the renunciation of real enmity that opens the door for the work of annihilation of an absolute enmity' (Schmitt 2004[1962], p. 67).

The issue of labelling, viewed through this prism, is informative regarding the importance of discourse for the definition of an armed conflict. As genocide claims, due to their totalising ambitions, do not figure within an acceptable conflict framework, the terrorist label, whether applied to groups (by the state) or to states (by the groups), is the most radical point in a line of potential conflict discourses.

\section{The political paradox of terrorism}

Although the always contested concept of terrorism could be tentatively defined, what is analytically relevant for this article is the discourse of terrorism, rather than the contested phenomenon itself. Still, the continuous application of the term to certain acts and contexts (such as when a car bomb explodes in the centre of a city, or when a suicide-bomber explodes in a bus full of people) has established the notion that those who commit those attacks are perpetrating terrorist acts. In that sense, there is the self-consciousness by these groups of the consequences of such acts which leads to the conclusion that terrorism is the dark beast of conflicts, or even more broadly, of political violence:

Terror occupies the upper reaches of the spectrum of political agitation, immediately above other types of political violence. Terror may be distinguished from these other types by its extranormal quality; that is, terror lies beyond the norms of violent political agitation that are accepted by a given society. (Thorton 1969, p. 76)

Furthermore, terrorism points to a relevant paradox: it is at the same time political and apolitical. As mentioned by Thorton, terrorism is understood as the most radical form of political violence. In that sense, it leads to the notion of terrorism as violent but still political. At the same time, such labelling prevents the acceptance of the 'other' and the recognition of their political legitimacy, and thus, terrorism cannot be fought on political grounds. It is this paradox that allows for a movement to be considered 'terrorist' (with whom a state cannot negotiate) at one stage, and a legitimate political actor some time later (with whom negotiations are possible). The talks between the Spanish government and Basque Homeland and Freedom (ETA), or the British government relations with the IRA, are examples of such ambiguity (see Bew et al. 2009). Regarding the latter, the Omagh bombing in Northern Ireland illustrates rather well the argument proposed here. In August 
1998, a car exploded in Omagh, Northern Ireland killing 29 people and wounding another 220. As mentioned by Richard Jackson (2005, p. 37), this act

could have been used by leaders in Britain and Northern Ireland to create another powerful grievance, as could other terrorist attacks by the Real IRA during this period. Such language, however, would probably have upset the fragile peace process at the time and would have renewed the cycle of violence, which is why it was avoided by British officials.

Tony Blair, for instance, considered the act as an 'appalling act of savagery and evil', further stating: 'These people will not win' (BBC NEWS 1998). The label 'terrorist' was not applied, nor a specific group identified. This reveals both the political significance of the terrorist label, as well as its ambiguity. The fact that those attacks occurred during peace negotiations shows that political actors have a clear notion of the 'weight' of naming someone a 'terrorist'.

\section{Terrorism and the normalisation of exceptional measures}

'The terrorist' label can be effective in reproducing the political structure and, hence, contribute to the protraction of a conflict. This leads to the normalisation of the term, as well as the policies associated with it. Using the Copenhagen School approach, the issue, by being securitised, is moved from the sphere of 'normal politics' to that of 'special politics' (Buzan et al. 1998) in which exceptional measures are defined in order to face the security issue. According to a growing literature on the relation between terrorism and the state of exception (see Agamben 2005, Huysmans 2006, Neal 2010), it could be argued that the use of the terrorist label and counterterrorism responses are usually associated with the adoption of exceptional measures, which, in turn, lead to the normalisation of the exceptional.

As the conflict unfolds and becomes part of a group/country's daily routine (Jabri 2006a, p. 54), 'special politics' become 'normal politics' and security discourses are infiltrated into almost all areas of society. In such contexts, "war permeates discourses on politics, so that these come to be subject to the restraints and imperatives of war and practices constituted in terms of the demands of security against an existential threat' (Jabri 2006a). In Israel, for example emergency governments have become the norm: '[w]hat started as a temporary transition mechanism during a "war of independence" quickly became and remained a permanent feature of the Israeli state' (Neocleous 2006, p. 202).

From then on, any decision taken within normal politics needs to take those security concerns into serious consideration, be it education or health policy. Directly or indirectly, the political life of that society becomes strongly limited by the securitised issue (Buzan et al. 1998). As articulated by Didier Bigo, in these contexts ' $\mathrm{t}$ ] he lines between security and liberty blur', and thus, '[1]iberty is not the limit of security but the condition of security, so security has no limits' (2000, p. 175). These security practices, although exceptional in 'normal times', become increasingly entrenched into the day-to-day life of societies, reaching the point in which 'new generations, who are growing up in an intractable conflict, have no conception of reality other than fighting and believe that it is normal to live in such a society' (Jeong 2008, p. 13). They are mutually the consequence of that securitised discourse and catalysts for its further reinforcement.

In order to illustrate the effects of these mechanisms, the article now turns to the case of the PKK in Turkey. It will be seen how the 'terrorist' label was reproduced in the build-up to the military incursion in northern Iraq during the winter of 2007-2008. 


\section{Turkey's discourse on the PKK}

The PKK was created in the 1970s by an Ankara University student, Abdullah Öcalan, during a period of strong political and social unrest in Turkey. As with many other Marxist movements created during this period, it advocated the need for an armed struggle in order to fulfil its goal: the creation of an independent, socialist Kurdish state (see Marcus 2007). In 1984, the PKK began its attacks against the Turkish state, the starting point of a conflict that would lead over the following 15 years to more than 30,000 deaths (UCDP 2010). In 1999, Öcalan was arrested in Kenya, after diplomatic incidents involving Greece, Italy and the United States, originating in a cease-fire call by Ankara. This period coincided with the beginning of a reformist period in Turkey that would lead to the European Union's acceptance of Turkey as a candidate member in 2005. During that time, several reform measures that were previously part of the PKK grievances discourse were taken, such as the enhancement of Kurdish cultural rights, as well as improving the socio-economic condition of south-east Turkey, largely composed of Turkish citizens of a Kurdish ethnic background. As mentioned by Bekdil (2007), '[i]n 2002, three years after the capture of Abdullah Öcalan, the Turks were almost forgetting about Kurdish terrorism'.

Independent of the merits and effectiveness of such measures, the PKK declared in June 2004 that those measures were far from satisfactory, and unilaterally declared an end to the cease-fire. From then on until 2008, the movement undertook several attacks on Turkish security and military forces; they were also accused ${ }^{8}$ by Turkish authorities of conducting attacks against civilian populations, particularly tourist resorts, killing or wounding more than 1500 people (Cagaptay and Dubowitz 2007).

\section{The context}

Since 2006, Turkey had been using all diplomatic channels available to try to convince the United States of the need to curb the PKK 'threat'. A trilateral cooperation mechanism was eventually established between Washington, Ankara and Baghdad. The results would, nonetheless, be far from what Turkish public opinion expected. This mechanism would eventually fail, with two of its original members - the Turkish representative, retired General Edip Başer (who antagonised the Turkish government), and the US representative, retired General Joseph Ralston - resigning during the process.

In April 2007, the Turkish military requested political authorisation for a cross-border operation in northern Iraq. This was not seen by the military as the sole solution to eradicating the PKK, but merely as a contribution to solving the problem. In a public statement in June that same year, Turkey's Chief of Defence Staff General Yaşar Büyükanit would make it clear that such an operation 'would bring benefits' (Turkish Daily News 2007b); or, as more emphatically put by the Land Forces Commander General Ilker Başbuğ, 'a big blow on them' (Turkish Daily News 2007b). The first visible action came in early June when the Turkish military created three interim security zones in south-east Turkey.

On 9 October 2007, the Supreme Board for the Fight Against Terrorism, composed of government members, military and security staff, issued an order for a cross-border operation. A few days later on 17th October, the Parliament would approve (507-19) a motion authorising the government to order the military to carry out an incursion into Iraq. On 23rd October, the Turkish Armed Forces (TAF) stepped up their operations against the PKK. With tens of thousands of Turkish troops in the south-east ready to enter northern Iraq, Turkey's Prime Minister, Recep Tayyip Erdoğan, went to the United States to meet George W. Bush on 5th November. After the failure of the first mechanism, the establishment of a 
more practical one, involving the sharing of intelligence between Washington and Ankara, was decided at the meeting. Soon after, Turkey began its series of five air bombardments against PKK bases in northern Iraq, followed by a military ground incursion. ${ }^{9}$ The operation was concluded after 8 days of incursion into northern Iraq. According to the TAF, 240 PKK fighters and 27 members of the Turkish security forces were killed in 8 days of fighting, and almost 800 PKK positions were destroyed (BBC NEWS 2008a).

After this brief contextualisation, the focus will now turn to the reproduction of the PKK's discourse as a terrorist threat. Here, two different aspects will be analysed. First, it will be seen what 'kind' of terrorists the PKK are portrayed as, and how this links with Turkey's structural political discourse; and second, the competing discourses regarding the solutions to the problem, relating them to the way the PKK was initially labelled.

\section{The 'terrorists'}

One of the main concepts in the political discursive structure of any polity is that of security, as it is a core element in the definition and reproduction of identities (see Campbell 1998, Williams 2006). In that sense, looking at official security doctrines or concepts (when they are present) gives us a clear advantage in understanding the political discursive structure under analysis. In the Turkish case, Article 2 of Law No. 2945 on National Security Council (NSC), and the NSC General Secretariat, define 'national security' as the:

[. . .] preservation and protection against the collective internal and external threats to the constitutional order of the state, its national existence, integrity, all of its political, social, cultural and economic interests and contractual rights in the international arena. (apud Arslan 2006, p. 26; author's emphasis)

Such a concept is simultaneously vague - it can be applied to almost anything - and narrow, as it only considers the existence of the state and not the safety or well-being of its citizens. Nonetheless, the concept identifies specific referent objects, such as the 'constitutional order', the 'national existence' and the 'integrity' of the state, concepts that can be found in the discourse about the PKK. For instance, when commenting on recent attacks undertaken by the PKK, Prime Minister Recep Tayyip Erdoğan declared,

[a]s long as we are firmly bound together, the treacherous separatist terrorist attacks will never attain its goal [...]. I want to declare this one more time: the struggle we lead against separatist terrorism that aims to destroy our unity and our constitutional order will continue with belief and determination. (Turkish Daily News 2007f)

In a keynote speech delivered at the beginning of the 2007-2008 academic year at the Turkish Military Academy, General Başbuğ, Turkish Land Forces Commander, signalled that, ' $[\mathrm{t}]$ he separatist terrorist movement is based on ethnic nationalism. Separatist terror aims to destroy the Turkish state and the unitary structure of Turkey' (Turkish weekly 2007; author's emphasis). In both cases, there was the explicit attachment of the 'terrorist threat' to the above-mentioned key concepts of the Turkish political discursive structure: 'unity', 'constitutional order' and the 'unitary structure of Turkey', as well as the mentioning of opposite concepts such as 'ethnic nationalism' and 'separatist'. The PKK therefore, embodied an ethnic nationalist project that intended to destroy the Turkish state and, as such, had to be eliminated.

But how do Turkish authorities define terrorism in a general sense? Terrorism is, according to the former Turkish Chief of Defence Staff, General Yasar Büyükanit (2007), 
'a form of violence that is consciously and politically motivated as well as a crime against humanity'. In the website of the Turkish Ministry of Foreign Affairs, one can also read that terrorism serves a 'specific "political” goal' (Ministry of Foreign Affairs 2007), and that it can be considered 'as an extreme form of expression, which is most contrary to the values of democracy, civilization and humanity' (Ministry of Foreign Affairs 2007).

Within this context, the PKK was singled out as 'one of the most dangerous terrorist organizations in the world' (Ministry of Foreign Affairs 2007). Still, such discourse, in itself, would place the PKK as an enemy, but a nonetheless 'legitimate' one. In that sense, a process of depoliticisation and dehumanisation of the movement also accompanied such claims. Regarding the first, the former National Intelligence Organisation (MIT) assistant secretary, Cevat Önes, commenting on a PKK attack declared 'The attack [. . .] showed that the PKK does not have a political aim any more. This attack indicates their defeat and loss of power' (Sabah 2008). Such claims reproduced a discourse in which, even if conceding that the PKK had some kind of political legitimacy in the past, the movement did not have any logic of existence anymore. As for the dehumanisation of the PKK, the military weekly reports summarised in the press were a case in point. Each week, the military weekly reports that cover the operations in the south-east mentioned the number of terrorists 'eliminated' (Today's Zaman 2007k) or 'rendered ineffective' (Today's Zaman 2007c), in opposition to the Turkish soldiers that had been 'wounded', 'killed' or even sometimes 'murdered', which also highlights the criminal dimension of the PKK.

The funerals of Turkish soldiers were emotional moments and a source of powerful images. They became paramount political moments, with thousands of people attending the ceremonies, political slogans exhibited and government members strongly criticised for not doing enough to counter the PKK. At one of those funerals, the Parliament Speaker, Bülent Arinç, declared 'We are continuing to shed tears, but we are not desperate. We are determined to fight terrorism until the very end. We will put an end to terror, we will finish it and our country will return to peaceful and happy days once again' (Today's Zaman $2007 \mathrm{k}$ ). It is relevant to highlight in this case the replacement of the PKK acronym for the sole word 'terrorism', and the promise of the return to a 'happy' and 'peaceful' past. It is also interesting to note the predominance in official discourse of a sense of defiance and bravery in the face of danger, as exemplified by the words of both Recep Tayyip Erdoğan (We will never be intimidated. We will continue progressing on our path with the same determination) and his Minister of Foreign Affairs, Abdullah Gül (No power will be able to resist before our nation's and state's unshakable will regarding this matter) (Turkish weekly June 2007).

One of the main issues in defining the PKK was actually the extent to which the terrorist label could be applied. For political leaders and military officials, there was a concern with separating the 'terrorists' from the Kurds, even though in different degrees. For the Turkish Prime Minister, for instance, '[t]he terrorist organization does not represent my citizens of Kurdish origin' (Today's Zaman 2007i); whereas for the main opposition party, it was not even a matter of speaking of a 'Kurdish problem' but, as put by the MP Recai Birgün, rather of a 'South-east problem' that was due to a problem of land distribution and to the archaic tribal divisions still existent in the region (Today's Zaman 2007h).

For others, though, those divisions were not as clear-cut. For Sunday Zaman's editorin-chief, Bülent Keneş, the previously existent political support of the Kurdish population in Turkey for the PKK was by 2007 non-existent. The movement's attacks could only be interpreted as 'acts of despair' in an attempt to drag Turkey into northern Iraq (24 June 2007). More sceptical about the disappearance of such support was General Büyükanit. In his opinion, there was still a certain level of complicity on the part of the population that 
made it harder to fight against the PKK: "The main reason preventing the success in the fight against terror is the collaborators. If a village headman or an imam lives peacefully in a village but plant bombs at night, how can you fight terror?' (Turkish Daily News 2007b).

The role of the Kurdish population in supporting the PKK was directly linked to the internal/external dimension of the problem. As can be read in the official AK Party programme, even though the PKK was enjoying 'intensive outside support': 'the fact that the region's population is attached to the unitary state structure, and the fact that the problem did not turn into an ethnic conflict with the common sense of our people, is proof that the issue can be solved as an internal affair' (JDP 2007).

This position was not consensual within Turkish political discourse, with many other relevant political actors externalising the problem, largely by linking it to developments in the Kurdish autonomous region in northern Iraq. For Mehmet Şandir, deputy chairman ${ }^{10}$ of the Nationalist Movement Party (MHP), a nationalist party with 71 seats in the Parliament,

[t]hese Barzani and Talabani-based efforts should be mentioned together with the PKK threat. The separatist terrorism of the PKK aims at making Turkey recognize a policy through armed terrorism. This political goal is to divide Turkey with its land, people and state. (Today's Zaman 2007j)

The appeal aimed at extending the terrorist label to both the (Kurdish) President of Iraq and the president of the autonomous Kurdish region in the north of the country, while once again underlining the dividing character of the PKK. For political commentator, Mehmet Ali Birand, Turkey's fight against the PKK was actually nothing more than a proxy war between Ankara and Erbil (the capital of the Kurdistan region in northern Iraq):

From the outside, there is an impression that the conflict between northern Iraq and Turkey is actually over the outlawed Kurdistan Workers' Party (PKK). But this outside view is the most misleading. Barzani uses the PKK card to rid himself of Turkey's pressure about Kirkuk and independence. Meanwhile, Turkey is trying to prevent an independent northern Iraq and prevent Kirkuk from becoming a completely Kurdish region. (Birand, 30 October 2007b)

The main opposition leader, Deniz Baykal, followed the same line, mentioning the 'covert war launched against Turkey through the PKK' (Hürriyet 2007).

Nonetheless, this externalisation process was not only done by extending the label to outside actors but also by pointing out the qualitative changes inside the PKK, highlighting its multi-national character. For retired Lt. Col. Şenol Özbek, '[p]reviously, most members of the terrorist organization were citizens of the Republic of Turkey, but this has changed. We are certainly faced with a new formation directed by Kurdish elements that have Iranian, Iraqi and Syrian roots' (Today's Zaman 8 June 2007a). Orhan Cengiz, columnist of the Turkish Daily News, preferred to talk of the PKK's 'Middle Eastern character', marked by the movement's 'suicide attacks' (October 2007).

Apart from the tendency to separate the Kurdish population from the PKK and to link the latter with external political actors (with a clear focus on the Iraqi Kurdish leaders Jalal Talabani and Massoud Barzani), there was also a strong discourse on the Kurdish Democratic Society Party (DTP) as the political wing of the PKK. For authors such as Soner Cagaptay (2007) and Mehmet Ali Birand (2007a), the DTP was the main body of the PKK, which worked as the military wing of the movement. According to the latter, 
[n]obody really knows how it works [PKK's decision mechanism]. We have scant information on the stages of decision making and implementation. We know just as little about the organization's configuration and the various tendencies that compose it. It has particularly, constantly changing and development-sensitive structure, whose net balances remain hazy. (5 December 2007a)

Nonetheless, a few sentences on, he claims that ' $[\mathrm{t}]$ he PKK dominates the Democratic Society Party (DTP)', even if not completely (Birand 2007a). Apparently, the lack of knowledge is not extended to the PKK's links with the DTP. For the then Republican People's Party (CHP) leader, Deniz Baykal, the DTP 'tries to legitimize them [the PKK], reflect their ideas and pull the government to negotiate with them' (Turkish Daily News 2007c). MHP leader Bahçeli goes even further, advocating that the 'supporters of terrorists are wandering in municipal buildings, university conference halls and even in the corridors of the Parliament' (Today's Zaman 2007g).

The DTP was the only political party with Parliament seats that rejected the PKK terrorist label. For one of the leading party figures, the mayor of Diyarbakir, Osman Baydemir, the PKK should merely be seen as 'armed Kurdish opposition' (Sabah 2007). As well as being the only political party not recognising the PKK as a terrorist movement, the DTP was also the one highlighting the political dimension of the movement. As argued by Selim Sadak, MP, the PKK imprisoned leader Öcalan 'is offering solutions to the problems of Turkey, whether we like it or not' (Çevik 2007).

In early November, the PKK kidnapped eight Turkish soldiers. They were eventually released with DTP mediation, leading to a public investigation of their role, as well as to several criticisms by all the other parties (Turkish Daily News 2007a). For CHP deputy leader, Cedvet Selvi, 'Turkey would never negotiate with terrorists. These attempts are merely intended to distract Turkey from a cross-border operation' (Turkish Daily News 2007a). The eight soldiers were subsequently sent to prison, facing charges of disobeying orders (Today's Zaman 2007e).

As can be seen, there was no consensus on the 'external' dimension of the PKK. In a sense, with the exception of the PKK being a terrorist movement, everything else associated with the problem seemed to be on contestable political grounds. This is made even clearer when we look at the suggested policy options, a topic of heated political debate.

The discussion about what policies to follow regarding the PKK was a source of heated political rhetoric. For Devlet Bahçeli, the nationalist MHP leader, Erdoğan should not be 'afraid' of facing the PKK: 'Don't escape; it is your duty to fight against terror. Don't be afraid, you are the prime minister make your decision. If you can't, resign right now!' The level of discursive aggressiveness is once again revealed in an increasingly dramatic discourse against Erdoğan: 'I know why you avoid fighting against terror and eliminating the terrorists. You can't run and you can't save yourself. You will pay the price. In Turkey or overseas, wherever you hide I'll find you and bring you back to Turkey' (Turkish Daily News 2007e).

The Turkish Prime Minister is here portrayed as 'weak', as he 'avoids fighting' and is willing to 'hide'. For that, he will 'pay' and when he tries to run away, due to his weakness, the MHP leader will 'bring him back', as if talking about an outlaw or criminal. This emotional tone is in stark contrast with the AK Party positions, arguably less dramatic in making their point. When considering the possibility of a cross-border operation, Prime Minister Recep Tayyip Erdoğan defended the need to 'avoid acting emotionally on the issue of a cross-border operation 「. . .1. So far, there have been 24 such operations. When 
you look back at its benefits, we see they have not been particularly effective' (Today's Zaman 12 October 2007f). Responding to opposition criticism, Erdoğan would further add a few weeks later: 'We are not cowboys with guns in our hands. We move with wisdom. We'll surely eliminate the terrorists' (Turkish Daily News 2007d; author's emphasis). It is interesting to compare this speech to the one by Bahçeli discussed above. Whereas in that speech, the MHP leader would, if necessary, be a lone avenger, here, Erdoğan clearly rejects that kind of approach, preferring to use 'wisdom' while guaranteeing the elimination of the PKK.

Amnesty ${ }^{11}$ for PKK members was a topic under discussion during this period, particularly after Erdoğan's remark about the possibility of PKK 'laying down its arms' (Today's Zaman 2007b). Contrary to the majority of potential measures discussed, amnesty for Kurdish rebels was one of the few ideas that attempted to directly tackle the problem without resorting to the usual militarised response. For Deniz Baykal, however, such claims were 'the discourse of the PKK. This talk is not directed at tackling terrorism, but rather is part of a strategy directed at letting terror acquire a result through negotiation' (Today's Zaman 2007b). It is worth highlighting the way in which the idea of 'negotiation' is understood here. For the Turkish opposition parties (with the exception of the DTP), the mere possibility of negotiations, and hence of politically recognising the PKK, was seen as an existential threat that must be avoided by denouncing the government's 'strategy'.

\section{The analysis}

This analysis attempts to answer the following questions: what is in the label and what is the political use and consequences of that label? First, it could be said that even if the Kurdish population was generally not linked to the terrorist label, other outside actors were. For a good part of Turkey's public and political opinion, the same label could be extended to the northern Iraq leaders (particularly Jalal Talabani and Massoud Barzani), as both they and the PKK were seen as part of the same problem. Adding to this was the notion that the PKK was an increasingly external problem, with its members coming from all over the Middle East, enhancing its Middle Eastern character that should be put in clear contrast with the Western, Kemalist Turkish identity. It is also important to note that Turkish authorities were careful to distinguish the separatists from the overall Kurdish population, clearly focusing on the former.

As for the relationship between Turkey's broader political structure and the use of the terrorist label, it was clear that the PKK was identified as a movement that attempted to go against the key concepts of the country's political discourse. By taking the NSC's security definition as one of the key concepts in Turkey's political structure, it could be seen that some of its core elements were reproduced in the discourse on the PKK, such as when the prime minister accused the movement of wanting to destroy the 'unity' and 'constitutional order' of the country (Turkish Daily News 2007f), two concepts that are integral to the NSC definition of security.

Another noticeable feature was the aggressive tone in which that discourse was reproduced, with some of the same features that were applied to the PKK (weakness, dividing character) being part of the broader political rhetoric within Turkish party politics. The dissemination of the terrorist label and attached concepts to categorise other political actors and parties, including the prime minister and the government, is particularly revealing of a normalisation of a supposedly exceptional discourse. This had obvious implications, not only for the normal functioning of Turkish democracy, but also for the potential solutions that could be found in order to tackle the conflict with the PKK. The aggressive tone with 
which the issue was politically treated led to the narrowing of potential policies. The military incursion in northern Iraq ended up being the most consensual measure (the DTP being the exception) among the political parties represented in Parliament.

Apart from the build-up to the TAF's military incursion in northern Iraq, the central issues in the political debate were both the closure (or not) of the DTP, and the possible amnesty law for the PKK combatants. Regarding the first, only the AK Party among the political parties assumed a position against the closure, even though highlighting that the recognition of the PKK as a terrorist group was a necessary requirement for the 'viability' of the DTP. Even when not supporting the closure, all the other political actors, commentators and the military seemed to have reached a consensus that the DTP was the political wing of the PKK. Nonetheless, instead of this being recognition of the PKK's political dimension, it rather functioned to question the DTP's political legitimacy. ${ }^{12}$

As for the amnesty debate, there was not even a consideration of the merits of such policy among the main political parties (the DTP being the exception). In spite of all the harm caused to the Turkish population over the years due to the clash between Turkish authorities and the PKK, the political actors linked with the CHP, MHP and AKP used such policy as a political weapon against each other. A distorted political tool in that case, as the debate and accusations moved from the merits of an amnesty policy to its meaning. For the opposition leaders, the amnesty issue was about surrendering to the PKK's wishes and opening the door for negotiations with the movement - that is recognising their political legitimacy.

\section{Conclusion}

As argued throughout this article, terrorism puts conflicts on the edge of the political. The terrorist label raises the question of whether a conflict fought under that label can still be defined as political, as it antagonises the 'other' in a quasi-non-reversible way: an 'other' that should be destroyed rather than kept as an 'enemy'. However, it is in the quasi that resides the political dimension of terrorism. Recurrent examples, such as the Omagh bombing, show that the terrorist label is often displaced, which opens the space for the resolution of the conflict.

The terrorist label should be seen as part of a larger discursive structure, in which the process of labelling stays in-between a constellation of key political terms and the definition of particular policies, all of which are intersubjectively constructed and reproduced. As a consequence, it is possible to contextualise this particular label within a larger political discourse, as well as to understand the long-term consequences of constantly using the terrorist label in the political debate. In addition, Ole Wæver's layered discursive structure provides the possibility of seeing change within continuity, and of identifying the political structures that underpin contexts of armed conflict.

When Ole Wæver's model was applied to the conflict between the Turkish state and the PKK, it was possible to understand how the labels used against the PKK in recent years (2007-2008) had been transposed to the political sphere as part of the normal political discourse among political parties. By focusing on Turkey's discourse on the PKK during the build up to the winter 2007-2008 military operations in northern Iraq, this article illustrated how the terrorism discourse ended up permeating the 'normal' political debate. The same words that were used to describe the 'terrorists' were also used by Turkish politicians to categorise political opponents. Turkey's political discourse on the PKK was thus normalised, leading to a generally aggressive tone of discussion that was not particularly helpful when trying to find an appropriate solution to the conflict. 


\section{Acknowledgement}

I am grateful for the valuable comments of Daniel Pineu, Richard Jackson and the two anonymous referees.

\section{Notes}

1. Based on Edward Azar's definition of protracted social conflict, I define 'armed conflict' as a hostile interaction, with fluctuation in intensity and frequency, going from intermittent periods of violence to open warfare (Azar et al. 1978, p. 50).

2. Labelling and the discursive construction of labels are thoroughly studied in the field of sociology, particularly in criminology (see Becker 1963). They are less so in the field of international relations, where the 'language turn' is still relatively recent (see Milliken 1999).

3. Here defined as a set of "elements considered to be constitutive of liberal democratic politics, including executive answerability, legislative scrutiny, a public sphere of discourse and interaction, equal citizenship under the law and [. . .] political legitimacy based on free and equal communicative practices underpinning social solidarity' (Jabri 2006a, p. 49).

4. According to the Uppsala Conflict Data Program, there were an estimated number of 458 casualties (for both sides) in 2007, and 501 in 2008, which is more than double when compared with 2006 (210). Years 2007 and 2008 together had almost as many casualties (959) as the whole period between 2000 and 2006 in which there were a total of 1082 (UCDP 2010).

5. Contrary to Neophytos Loizides' use of language within the context of elite framing, in which there is a manipulation in the construction of framing discourses $(2008$, p. 281), this article follows a constructivist (see Jabri 1996, Klotz and Lynch 2007) approach in which discourse is intersubjectively constructed between agents.

6. As pointed out by Alper Kaliber and Nathalie Tocci (2010), other civil society actors have traditionally had, either voluntarily or involuntarily, a limited role to play in Turkey's political discourse regarding highly sensitive issues such as this one.

7. Even though the role of newspapers in English- in non-English-speaking countries is a fascinating topic, particularly for the use of discourse analysis in countries about which the researcher does not have a good command of the native language, this article does not attempt to deal with this issue and takes the information obtained from these sources as reliable translations of the original source.

8. The expression 'being accused' is used in this context, as the PKK has rarely acknowledged any of these attacks.

9. It is unclear how many troops were involved in the mission. Early reports from Turkish National Television mentioned 10,000 troops involved, whereas both the US and Iraqi Kurdish officials reported the involvement of just a few hundred soldiers (BBC News 2008b).

10. As highlighted by Neophytos Loizides, there is a 'strong party discipline characterizing the Turkish political culture' (2008, p. 283), which makes statements such as this quite representative of the whole party.

11. In the past, Turkey passed seven amnesty laws, in 1985, 1988, 1990 and 2000. Accordingly, 1900 people benefited from this law, with only 2 people being reported as having re-joined the PKK (Today's Zaman 2007d).

12. Turkey's Constitutional Court eventually closed down DTP in December 2009.

\section{References}

Agamben, G., 2005. State of exception. Chicago, IL: The Chicago University Press.

Arslan, Z., 2006. Government. In: Ü. Cizre, ed. Almanac Turkey 2005. Security sector democratic oversight. Istanbul: TESEV/DCAF, 26-35.

Azar, E., Jureidini, P., and McLaurin, R., 1978. Protracted social conflict: theory and practice in the Middle East. Journal of Palestine Studies, 8 (1), 41-60.

BBC News, 1998. Omagh bombing kills 28. BBC News [online]. 16 August. Available from: http://news.bbc.co.uk/2/hi/events/northern_ireland/latest_news/152156.stm [Accessed 20 February 2009].

BBC News, 2008a. Iraq troop withdrawal baffles Turks. BBC News [online]. 29 February. Available from: http://news.bbc.co.uk/2/hi/europe/7272108.stm [Accessed 20 February 20091. 
BBC News, 2008b. Turkey border tensions fuel confusion. BBC News [online]. 22 December. Available from: http://news.bbc.co.uk/2/hi/europe/7259739.stm [Accessed 22 February 2009].

Becker, H., 1963. Outsiders: studies in the sociology of deviance. New York: Free Press.

Bekdil, B., 2007. Tayyip Erdogan is trying to tell us something. Turkish Daily News, 15 June.

Bew, J., Frampton, M., and Gurruchaga, I., 2009. Talking to terrorists: making peace in Northern Ireland and the Basque country. London: Hurst \& Company.

Bhatia, M., 2005. Fighting words: naming terrorists, bandit, rebels and other violent actors. Third World Quarterly, 26 (1), 5-22.

Bigo, D., 2000. When two become one: internal and external securitisations in Europe. In: M. Kelstrup and M.C. Williams, eds. International relations theory and the politics of European integration: power, security and community. London: Routledge, 171-204.

Bilgin, P., 2007. Making Turkey's transformation possible: claiming 'security-speak' - not desecuritization!. Southeast European and Black Sea Studies, 7 (4), 555-571.

Birand, M.A., 2007a. Let's pray Apo doesn't die' (!). Turkish Daily News, 5 December.

Birand, M.A., 2007b. We always fight with northern Iraq over Kirkuk. Turkish Daily News, 30 October.

Büyükanit, Y., 2007. Ipek Yolu 2007 General/Amiral Semineri [Silk road 2007 General/Admiral seminar opening speech]. Available from: http://www.tsk.tr [Accessed 15 January 2008].

Buzan, B., Wæver, O., and de Wilde, J., 1998. Security: a new framework for analysis. Boulder, CO: Lynne Rienner.

Cagaptay, S., 2007. Can the PKK renounce violence? Terrorism resurgent. Middle East Quarterly, Winter, 2007, 45-52.

Cagaptay, S. and Dubowitz, M., 2007. A deadly stumbling block named PKK. Op-ed, The Washington Institute for Near East Policy.

Campbell, D., 1998. Writing security: United States foreign policy and the politics of identity. Manchester: Manchester University Press.

Cengiz, O.K., 2007. The Kurdish question: Dejà vu!. Turkish Daily News, 6 October.

Çevik, I., 2007. Sadak: Kurdish deputies won't act like militants in Parliament. The New Anatolian, 17 April.

De Swaan, A., 1997. Widening circles of disidentification. Theory, Culture \& Society, 14 (2), $105-122$.

Der Derian, J., 1995. The value of security: Hobbes, Marx, Nietsche, and Baudrillard. In: R.D. Lipschutz, ed. On security. New York: Columbia University Press, 24-45.

Diez, T., 1999. Speaking 'Europe': the politics of integration discourse. Journal of European Public Policy, 6 (4), 598-613.

Fierke, K., 2007. Constructivism. In: T. Dunne, M. Kurki, and S. Smith, eds. International relations theories: discipline and diversity. New York: Oxford University Press.

Guelke, A., 2006. Terrorism and global disorder. London: I.B. Tauris.

Hürriyet, 2007. CHP's Deniz Baykal on recent PKK attacks: there is a secret war taking place against Turkey. Hurriyet [online], 22 October. Available from: http://www.hurriyet.com.tr/ english/7534119. asp?gid=74\&sz=61778 [Accessed 25 March 2009].

Huysmans, J., 2006. International politics of exception: competing visions of international political order between law and politics. Alternatives, 31, 135-165.

Jabri, V., 1996. Discourses on violence: conflict analysis reconsidered. Manchester: Manchester University Press.

Jabri, V., 2006a. War, security and the liberal state. Security Dialogue, 37 (1), 47-64.

Jabri, V., 2006b. Revisiting change and conflict: on underlying assumptions and the de-politicisation of conflict resolution. In: M. Fischer and B. Schmelzle, eds. Berghof handbook for conflict transformation [online]. Available from: http://www.berghof-handbook.net [Accessed 20 January 2008].

Jackson, R., 2005. Writing the war on terrorism: language, politics and counter-terrorism. Manchester: Manchester University Press.

Jacoby, T., 2010. Political violence, the 'war on terror' and the Turkish military. Critical Studies on Terrorism, 3 (1), 99-118.

Jeong, H., 2008. Understanding conflict and conflict resolution. London: Sage.

Justice and Development Party, 2007. Development and democratization. Party Programme. Available from: http://eng.akparti.org.tr/english/partyprogramme.html [Accessed 5 January วกกั1 
Kaliber, A. and Tocci, N., 2010. Civil society and the transformation of Turkey's Kurdish question. Security Dialogue, 41 (2), 191-215.

Keneş, B., 2007. PKK's Russian roulette and the cross-border incursion. Today's Zaman, 24 October 2007.

Klotz, A. and Lynch, C., 2007. Strategies for research in constructivist international relations. London: M.E. Sharpe.

Koğacioloğlu, D., 2004. Progress, unity, and democracy: dissolving political parties in Turkey. Law \& Society Review, 38 (3), 433-462.

Loizides, N., 2008. Elite framing and conflict transformation in Turkey. Parliamentary Affairs, 62 (29), 278-297.

Marcus, A., 2007. Blood and belief. The PKK and the kurdish fight for independence. New York: New York University Press.

Milliken, J., 1999. The study of discourse in international relations: a critique of research and methods. European Journal of International Relations, 5 (2), 225-254.

Ministry of Foreign Affairs, 2007. Concept and ideology of terrorism. Available from: www.mfa.gov.tr [Accessed 28 January 2008].

Mouffe, C., 1993. The return of the political. London: Verso.

Nadarajah, S. and Sriskandarajah, D., 2005. Liberation struggle or terrorism? The politics of naming the LTTE. Third World Quarterly, 26 (1), 87-100.

Neal, A., 2010. Exceptionalism and the politics of counter-terrorism: liberty, security and the politics. London: Routledge.

Neocleous, M., 2006. The problem with normality: taking exception to 'permanent emergency'. Alternatives, 31, 191-213.

Risse, T., 2004. Social constructivism and European integration. In: A. Winer and T. Diez, eds. European integration theory. New York: Oxford University Press, 159-176.

Sabah, 2007. The PKK is armed opposition. Sabah, 10 July.

Sabah, 2008. 'Bombing in Diyarbakir is the PKK's suicide'. Sabah, 7 January.

Schmitt, C., 2004 [1962]. The theory of the partisan: a commentary/remark on the concept of the political. East Lansing, MI: Michigan State University Press.

Shaw, M., 2007. What is genocide? Cambridge: Polity Press.

Thorton, T.P., 1969. Terror as a weapon of political agitation. In: H. Eckstein, ed. Internal war: problems and approaches. London: The Free Press of Glencoe, 71-99.

Today's Zaman, 2007a. Tension remains high as security on Iraq border maximized. Today's Zaman, 8 June.

Today's Zaman, 2007b. Amnesty debate raises tension in politics. Today's Zaman, 21 November.

Today's Zaman, 2007c. Army repels new PKK attack, kills more than 30 terrorists. Today's Zaman, 26 October.

Today's Zaman, 2007d. Çiçek reaffirms PKK amnesty not on table. Today's Zaman, 22 November.

Today's Zaman, 2007e. Eight soldiers freed by PKK face up to 20 years. Today's Zaman, 13 November.

Today's Zaman, 2007f. Iraq motion next week, no rush for incursion. Today's Zaman, 12 October.

Today's Zaman, 2007g. MHP leader Bahçeli accuses Barzani of heading the PKK. Today's Zaman, 24 October.

Today's Zaman, 2007h. Parties see no 'Kurdish problem' in Turkey. Today's Zaman, 14 July.

Today's Zaman, 2007i. PKK not representative of Turkey's Kurds, says Prime Minister Erdogan. Today's Zaman, 8 December.

Today's Zaman, 2007j. Political parties' Iraq policies challenge each other. Today's Zaman, 13 July. Today's Zaman, 2007k. Tears and anger on display at martyrs' funerals. Today's Zaman, 12 June.

Turkish Daily News, 2007a. DTP faces probe on soldier rescue. Turkish Daily News, 6 November.

Turkish Daily News, 2007b. Duel of numbers between government and the military on PKK presence. Turkish Daily News, 28 June.

Turkish Daily News, 2007c. Opposition says government soft on terror. Turkish Daily News, 9 October.

Turkish Daily News, 2007d. Gov't, opposition at odds over PKK. Turkish Daily News, 21 November.

Turkish Daily News, 2007e. Opposition criticizes gov't for blocking the military. Turkish Daily News, 11 June.

Turkish Daily News, 2007f. Struggle for unity in national diversity, Turkish Daily News, 29 October. 
Turkish Weekly, 2007. Turkey cries for her losses in Sirnak. Journal of Turkish Weekly, 11 June.

Uppsala Conflict Data Program, 2010. UCDP Database. Uppsala University. Available from: http://www.ucdp.uu.se/database [Accessed 18 November].

Wæver, O., 2002. Identity, communities and foreign policy: discourse analysis as a foreign policy theory. In: L. Hansen and O. Wæver, eds. European integration and national identity: the challenge of the nordic states. London: Routledge, 20-49.

Williams, M.C., 2006. Culture and security: symbolic power and the politics of international security. New York: Routledge. 